\title{
Effects of Social Media on Civil and Political Participation and a Field of Survey over on Facebook
}

\author{
Fatma Kamiloğlu, İstanbul Aydın University, Turkey \\ Emre Erdoğan, İstanbul Bilgi University,Turkey
}

\begin{abstract}
Turkish youth is characterized with low level of political participation. Several surveys showed that less than 10 percent of Turkish youth are active in political parties and civil society organizations. There are cultural and behavioral reasons of this inertia. Meanwhile, Facebook, the most important social network site is widely used in Turkey and Turkish users form the 6th biggest population in Facebook but level of political participation in Facebook is unknown. By using data collected from 563 university students, this paper showed that there different dimensions of political participation in Facebook and level of activity in these dimensions is dependent on several factors. Demographic factors are important in "active participation", meanwhile participation through "direct" or "indirect" expression are affected by Facebook usage patterns of respondent as well as "real life" political activities and perceptions.
\end{abstract}

Keywords: Facebook, political parties, participation 


\section{Introduction}

Turkish youth is characterized with their inertia to participate in politics. More than one survey showed that only 10 percent of young people living in Turkey are involved in direct politics such as becoming a member of a political party or directly participating in canvassing and other conventional political activities. Participation in unconventional politics is also limited, Turkish youth don't prefer to participate in boycotts or meetings, as well as being a member of a civil society organization is not popular among them. There different explanations of this inertia, from a deterministic explanation about political culture to behavioral approach emphasizing rules and regulations designed to prevent political participation.

In the meantime, social network sites, especially Facebook is very popular among Turkish Internet users. According to official statistics, number of Facebook users is more than 30 million and 90 percent of "online" citizens have Facebook account. With these figures, Turkey composes the $6^{\text {th }}$ biggest Facebook nation in the world.

Several scholarly works showed that Internet and Facebook provides new avenues for political participation and Facebook users are becoming more active in political life. This paper targets to answer the question about to what degree new avenues of political participation may affect the inertia of Turkish youth in political life. In order to answer this question we believe that multidimensionality of political participation in Facebook has to be accepted. Hence, we propose that different factors will affect different levels of political participation in different dimensions, in addition to some common factors.

Data collected with an online survey from 563 university students is employed to discover different dimensions of political participation in Facebook. Through multivariate techniques, we tried to show determinants of political participation by using socio-demographic and political factors in addition to usage patterns of Facebook. 


\section{Political Participation and Facebook}

Development and wide use of Internet created a significant opportunity space for further participation of citizens. Growing number of users and platforms, coupled with rapid technological innovations such as smartphones and tablet PCs; are accepted as new avenues for further political participation for citizens. According to this optimistic view, Internet has been accepted as newly emerging media as information provider, allowing users to access diversified sources of information and different viewpoints, a scarce resource during the hegemony of conventional mass media. Such a multiplicity of viewpoints empowers citizens and raises awareness about collective problems (Mutz, 2002; Kwak et. al., 2005, Bennet and Iyengar, 2008).

Internet also facilitates political and civic participation of users acting as a resource of political discussion and deliberation among participants. Different than the traditional media, users may be involved to information production process through their comments and they can easily discuss with other users. Last surveys showed that Internet users spend significant time to use instant messaging and other facilities to communicate with each other (Karakaya, 2005; Shah et. al., 2005, Baumgartner and Morris, 2010). Such a deliberation leads to increased interest on politics, hence increased political participation.

Another way in which Internet usage contributes to political participation of individuals is through accumulation of social capital defined as "elements of social life as networks, norms, and trust that provide the means for citizens to resolve collective action problems" (Scheufeleand Shah, 2000, p. 113). As the Internet opens avenues for collaboration and communication of individuals with others, they are becoming more connected and their stock of social capital increases. Consequently these individuals tend to be more oriented towards political participation (Valenzuela et. al., 2008, Quintelier and Vissers, 2008).

Facebook, the most popular social networking site deserves a special attention in this discussion of political participation and Internet. First of all, it is the most widely used social network around the world. According to the official website of Facebook, number of active users is about 845 millions, where 80 percent of active users are outside the U.S. and Canada. Number of daily active users is more than 483 million. These figures show that Facebook reaches to about 12 percent to the world population, while penetration ratio is about 50 
percent for the developed world. In Turkey, there are more than 30 million Facebook users, with a penetration ratio of 40 percent for overall population. Among online users, this ratio is 90 percent, meaning that almost every online user has a Facebook account. With these figures, Turkish users form the $6^{\text {th }}$ biggest Facebook nation in the world ${ }^{1}$.

In addition to this scale advantage, Facebook is important for political participation due to tools provided to users. Vitak and her friends list possible political activities as follows:

"For example,users can join political groups, download candidate applications,and share their political opinions through the manycommunication tools on the site. Users can view their friends'activities by scrolling through the News Feed on their homepage, and they can comment on friends' posts, thus engagingin active conversation about political issues. From a resourceperspective, these affordances also offer affordable (i.e., free)opportunities to develop civic engagement skills with little tono additional time costs for users of Facebook, while simultaneously having access to a potentially large enough "public" to develop civic skills" (2011, p.2)

Hence, it is expected that such a tool positively contributes to political participation level of its users.

In the Turkish case, this opportunity provided by Facebook is very crucial, because Turkish society is characterized with very low level of political participation as a result of several cultural and historical characteristics (Erdoğan, 2009). Last available surveys show that only 31 percent of Turkish citizens are interested with politics, proportion of those participated in meetings is less than 5 percent and only 7 percent of Turkish citizens are members of a civil society organization (Kalaycıŏlu, 2008).

This lack of civic and political participation is also observable among young people. Several studies conducted during a decade showed that 10 percent of Turkish youth is a member of a political party, less than 7 percent of them actively participated in political campaign activities, meetings and boycotts are conducted by about 10 percent of them (Erdoğan, 2009).

\footnotetext{
${ }^{1}$ For the number of Facebook users see the official website of Facebook: http:/ / newsroom.fb.com/http:// newsroom.fb.com/content/default.aspx?NewsAreaId=22; about Turkey see http:/ / www.socialbakers.com/facebook-statistics/turkey
} 
Reasons of this political entropy are innumerable and policies to increase this score is beyond the limit of this paper. However, considering the opportunities provided by Internet and Facebook and very high level of Facebook penetration, we believe that understanding the dynamics of political participation in Facebook may provide significant information for those are interested with young political participation.

\section{Methodology, Research Question and Hypotheses}

Our research question in this paper may be stated as follows: "What are the factors affecting young people's political participation in Facebook?" This major question is followed by another research question: "What are the dimensions of political participation in Facebook?" Within this research question, our major hypotheses are listed as follows:

H1: Political Participation in Facebook is affected by demographic and socioeconomic factors.Considering the fact that politics is a matter of resource, it is expected that one having access to critical resources such as money, socioeconomic status or time, tends more to participate. Hence, it is expected that political participation in Facebook is more often among upper segments of society.

H2: Political Participation in Facebook is affected by political participation in the real life. Political participation may be a medium-free action. People already participating to politics may continue to their activities in Facebook.

H3: Political Participation in Facebook is affected by Facebook usage patterns. Political participation in Facebook may be a subset of Facebook activities for users, and different usage patterns may lead different levels of political participation.

H4: Political Participation in Facebook is multidimensional. Considering the fact that political participation in real life is multidimensional, it is expected that there are different dimensions of political participation in Facebook.

All these hypotheses will be tested by using multivariate statistical techniques to prevent spurious correlation.

\section{Methodology}

Data presented in this paper is collected between 4th and 20th of April 2012, with participation of 563 university students having a Facebook account. According to Facebook 
statistics, number of Facebook users who are university students is about 946620. Since our sampling strategy was Snowball Sampling, it's not possible to calculate a margin of error; however this sample size would have a margin of error of 4 percent, if it would be collected with simple random sampling methodology (Bryman, 2008; Salganik and Heackathorn, 2004).

In the recruitment of participants, different strategies are preferred by the research team. Team prepared a Facebook advertisement and this advertisement is shown to target population by using Facebook advertising campaign management tool. According to Facebook statistics, this advertisement has been shown more than 3 million times to 392946 users with an average of 8 times per user and 1657 users have clicked on it. By using our database, we calculated that 219 people clicked this advertisement completed this survey. It means that our advertisement had access to 41 percent of total target population, 4 per thousand of them has clicked on it and 13 percent of those clicked completed the survey. We don't have information about other Facebook campaigns to compare our reach statistics, but our previous research projects showed that expected return ratio is less than 6 per thousand by using Internet databases.

Parallel to Facebook advertisement, we conducted a snowball sampling methodology, a group of students are invited to complete this survey and they are asked to invite their friends to participate to this project. 344 students participated in the project and completed the survey. Snowball or Referral sampling strategy is highly criticized of not being representative and sometimes this methodology may create a bias. However we believe that it's the most appropriate method for collecting data from unknown populations and lists are not available to prepare a sampling framework.

When we controlled the differences between these two strategies of sampling, we didn't observe any significant difference on behavioral questions, therefore we can assume that these two sampling strategies accessed to same profile of users. 


\section{Findings}

\section{Profile of Participants}

Target population of the project was university students between 18-27 ages having a Facebook account. Basic demographic information about participants is as follows:

- Average age of participants is 22.8 with a standard deviation of 3.4 years;

- 55 percent of them is man, and 45 percent is woman;

- 15 percent of participants are working parallel to university education;

- 21 percent of participants are from state universities of Istanbul, 38 percent are from private universities of Istanbul and remaining 40 percent is from universities abroad.

When education of parents are analyzed as an indicator of socioeconomic status, it's observed that 40 percent of fathers have an education of less than secondary school, 30 percent of them have a secondary school graduation and percentage of those having a tertiary degree is 30 percent. 52 percent of mothers of participants have an education less than secondary school. Those graduated from secondary school forms 29 percent and graduates of university and higher are only 16 percent.

Median household income is between 2000 and 2500 TL, while 30 percent of participants have a household income less than $1500 \mathrm{TL}$ and 20 percent of them has an income higher than 4500 TL.

\section{Dimensions of Political Activities in Facebook}

There are alternative ways of political participation in Facebook, and it changes from being a passive spectator of political discussions, such as following political activities, being a "fan" of a political candidate; to share political information such as link, news column; or to take a part in deliberation through discussion or chatting. There is a room for further political involvement: user can form a political group or join a group formed by other people. In order to understand level of political involvement, we prepared a list of possible activities and asked participants how frequently they are involved in those activities, with a four point scale., based on a previous work conducted by (Vitak et. al., 2010). Below table presents our findings. 
Table 1. Political Activities in Facebook (Percentage of "I did" answers and Mean)

\begin{tabular}{|c|c|c|}
\hline & Percentage & Mean \\
\hline Sharing a link about politics & $\% 33.7$ & 1.98 \\
\hline Sharing a news column about politics & $\% 33.5$ & 1.98 \\
\hline Following political activities & $\% 32.8$ & 1.97 \\
\hline Posted a status update about politics & $\% 32.6$ & 1.98 \\
\hline "Like" a page of a political candidate & $\% 29.1$ & 1.84 \\
\hline $\begin{array}{l}\text { Discussed political information in a Facebook } \\
\text { message }\end{array}$ & $\% 28.8$ & 1.87 \\
\hline Became a "fan" of a political candidate & $\% 27.2$ & 1.77 \\
\hline $\begin{array}{l}\text { Posted a video that has something to do with } \\
\text { politics }\end{array}$ & $\% 25.9$ & 1.82 \\
\hline $\begin{array}{l}\text { Posted a photo that has something to do with } \\
\text { politics }\end{array}$ & $\% 23.4$ & 1.76 \\
\hline $\begin{array}{l}\text { Added or deleted an application that deals with } \\
\text { politics }\end{array}$ & $\% 22.1$ & 1.70 \\
\hline Joined a group about politics & $\% 21.6$ & 1.67 \\
\hline $\begin{array}{l}\text { Added or deleted political information from their } \\
\text { Facebook profile }\end{array}$ & $\% 21.3$ & 1.68 \\
\hline $\begin{array}{l}\text { Discussed political information using Facebook } \\
\text { "chat" }\end{array}$ & $\% 18.8$ & 1.68 \\
\hline $\begin{array}{l}\text { Posting something about politics to another person's } \\
\text { wall }\end{array}$ & $\% 16.9$ & 1.62 \\
\hline Took quiz that about politics & $\% 12.3$ & 1.48 \\
\hline Posted a photo about a local political meeting & $\% 9.4$ & 1.41 \\
\hline Forming a group about politics & $\% 6.9$ & 1.26 \\
\hline
\end{tabular}

Among alternative ways of political participation, sharing is the most popular one. One third of participants said that they share links about politics or news columns. Similarly, one third of them followed a page of a political candidate, liked it or became a fan of him. At the other end, more active ways of participation are not popular. Only 7 percent of participants formed a group about politics, 9 percent of them posted a photo about a local political meeting. 
Although people are open to state their own position; they don't prefer direct discussion through Facebook chat (19 percent) or posting something about politics to another person's wall (17 percent). This separation of activities gives some clues about "netiquette" of politics in Facebook. Participants can state their position, they can discuss openly; however direct discussion is not welcomed.

Apart this differentiation of activities, above table shows that political activities are not popular among Facebook users, the most popular activity has been performed by only one third of respondents. Our multivariate analyses target to show which factors affect this preference of participating in Facebook.

Table 2. Dimensions of Political Activities in Facebook (Factor Loadings)

\begin{tabular}{|llll|}
\hline & Factor 1 & Factor 2 & Factor 3 \\
\hline $\begin{array}{l}\text { Added or deleted political information from their } \\
\text { Facebook profile }\end{array}$ & & $\mathbf{0 . 5 5}$ & 0.30 \\
\hline $\begin{array}{l}\text { Added or deleted an application that deals with } \\
\text { politics }\end{array}$ & 0.47 & $\mathbf{0 . 6 5}$ & 0.22 \\
\hline $\begin{array}{l}\text { Became a "fan" of a political candidate } \\
\text { "Like" a page of a political candidate }\end{array}$ & 0.19 & $\mathbf{0 . 8 9}$ & 0.21 \\
\hline $\begin{array}{l}\text { Discussed political information in a Facebook } \\
\text { message }\end{array}$ & $\mathbf{0 . 6 8}$ & 0.35 & 0.28 \\
\hline $\begin{array}{l}\text { Discussed political information using Facebook } \\
\text { "chat" }\end{array}$ & 0.39 & 0.20 & $\mathbf{0 . 5 1}$ \\
\hline $\begin{array}{l}\text { Joined a group about politics } \\
\text { posted a status update about politics }\end{array}$ & $\mathbf{0 . 4 8}$ & $\mathbf{0 . 5 4}$ & $\mathbf{0 . 3 5}$ \\
\hline $\begin{array}{l}\text { Posted a photo that has something to do with } \\
\text { politics }\end{array}$ & $\mathbf{0 . 7 6}$ & 0.26 & 0.20 \\
\hline $\begin{array}{l}\text { Posted a video that has something to do with } \\
\text { politics }\end{array}$ & $\mathbf{0 . 7 8}$ & 0.26 & 0.31 \\
\hline $\begin{array}{l}\text { Posted a photo about a local political meeting } \\
\text { Posting something about politics to another }\end{array}$ & 0.56 & 0.18 & $\mathbf{0 . 5 9}$ \\
\hline & & & 0.22 \\
\hline
\end{tabular}




\begin{tabular}{|llll|}
\hline Sharing a link about politics & $\mathbf{0 . 8 2}$ & 0.31 & 0.24 \\
\hline Took quiz that about politics & 0.29 & 0.21 & $\mathbf{0 . 7 6}$ \\
\hline Sharing a news column about politics & $\mathbf{0 . 7 9}$ & 0.20 & 0.25 \\
\hline Forming a group about politics & 0.11 & 0.23 & $\mathbf{0 . 8 7}$ \\
\hline Following political activities & $\mathbf{0 . 6 5}$ & 0.25 & 0.24 \\
\hline Explained Variance & $\mathbf{3 2 . 0 3}$ & $\mathbf{1 9 . 4 5}$ & $\mathbf{1 9 . 1 2}$ \\
\hline & Indirect & Direct & Political \\
& Expression & Expression & Activity \\
\hline
\end{tabular}

Factor analysis of different political activities in Facebook produced three major dimensions of political participation explaining 70 percent of total variation. First dimension is highly loaded by posting (a status update, a photo, and a video), sharing (a link or a news column) and following. It explains 32 percent of total variation. Common characteristic of all these activities is indirect expression of political identity of respondent. By posting something or sharing a link or a news column; she expresses her political identity through reproduction/replication of available information. Her political identity becomes visible with her collection of these items. Since these items don't include a direct reference to political identity of user; it is a way of indirect expression of who she is as a political person. Hence, this dimension is labeled as "indirect expression".

Second dimension explains almost 20 percent of total variation and it is correlated with becoming a fan of a political candidate, "liking" a page of a political candidate or adding/deleting an application with politics or political information. This kind of Facebook activities are more direct way of expressing political identities. If a user "likes" a page of a politician or political party, her political identity becomes apparent for other users. Similarly, adding some political information in her profile, directly inform other users about her political identity. Consequently, we labeled this dimension as "direct expression".

Final dimension explaining almost 20 percent of total variation is labeled as "political activity", because it is more correlated with actions related with political activism. For example, this dimension is correlated with political discussion (through Facebook chat or writing on other's wall). It is more open to discussion and interaction with others. Difference 
between first and third dimensions seems to be initiative taken by user. In the first dimension, user only puts some information on her page, and waits for intervention of other people. In the third dimension, user is intervening through writing on somebody else's wall, chatting or forming a Facebook group.

These dimensions will be used as dependent variables in our multivariate analyses.

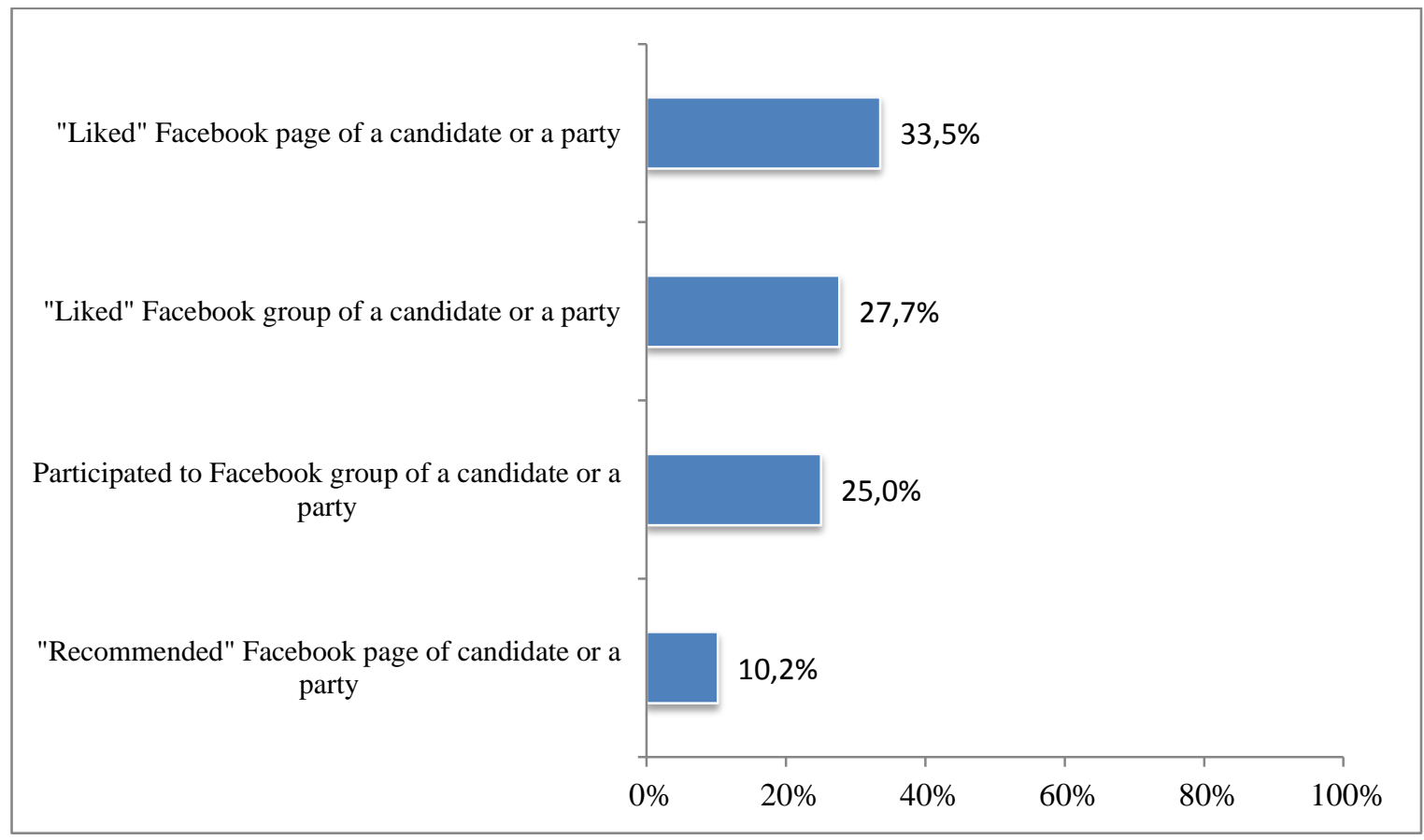

Figure 1. Facebook Political Participation in June 2011 General Elections

When political activities of participants on Facebook during June 2011 General Elections are analyzed, it is observed that, these kind of political activities were not popular. The most popular activities, "liking Facebook page of a candidate or a party" and "liking Facebook group of a candidate or a party" performed by only one third of participants. One quarter of respondents said they participated in Facebook group of a candidate or a party. Recommendation, a relatively more active behavior only performed by 10 percent, indicating that our respondents preferred more passive ways of political participation or abstained from political participation.

We composed an index of political activity by simply counting activities performed by users. This index changes between 0 and 4, meaning that if a respondent did all these activities, her 
score would be 4 . The opposite pole shows that respondent never did them. Cronbach's Alpha measuring reliability of this index is 0.81 , showing a very high level of reliability.

Another possible factor pushing people to participate in Facebook is one's perception about effectiveness of this tool. If she perceives Facebook as an effective environment for political activities, she will be tended to further political participation.

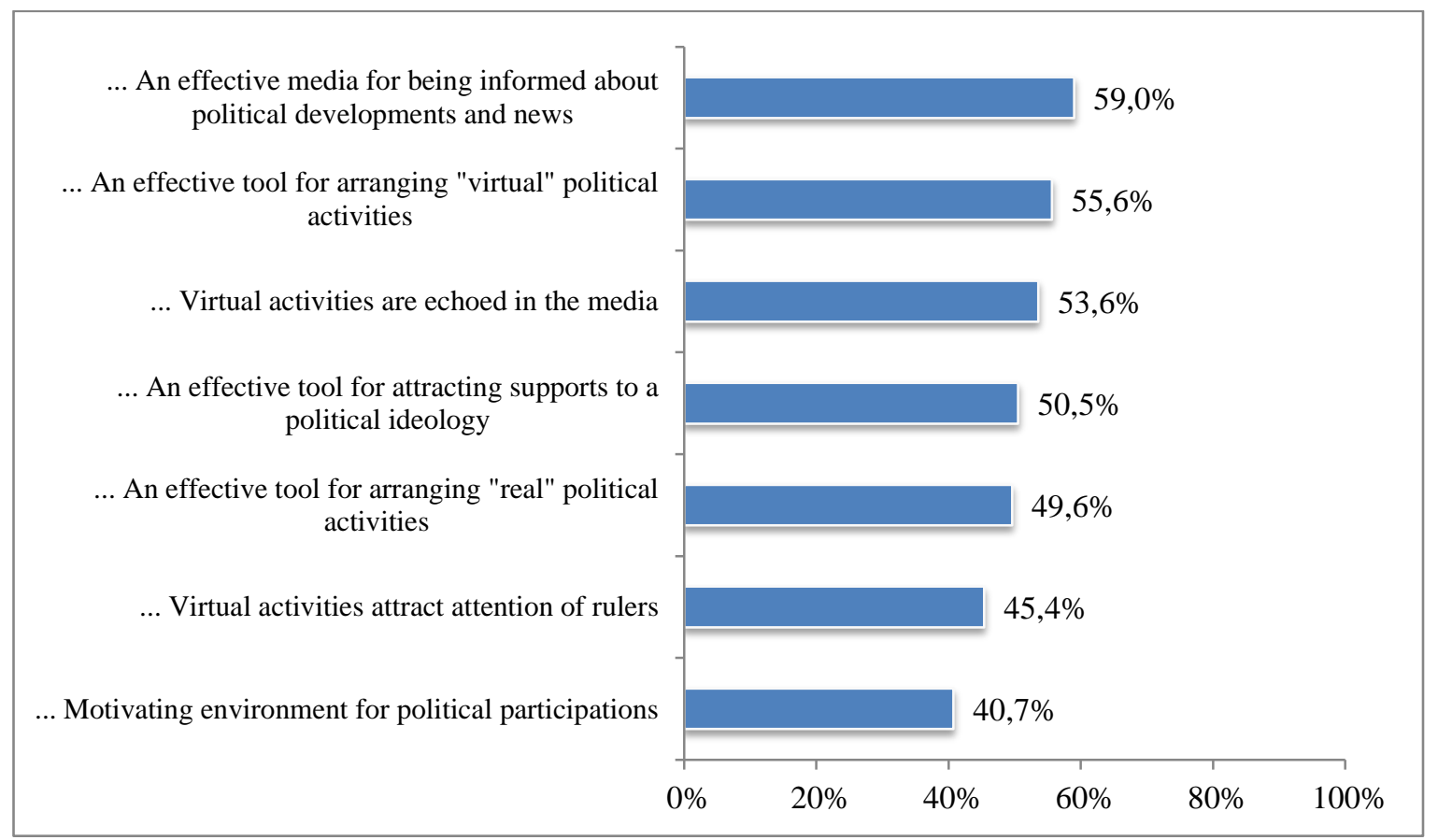

Figure 2. Perceptions about Political Effectiveness of Facebook ("Facebook is...", Percentage of "Agree" Answers)

Above figure shows that participants perceive Facebook as an effective tool for being informed (59 percent) and arranging "virtual" political activities (56 percent). They also believe that virtual activities are echoed in the media. And, they agree that Facebook is an effective tool for attracting supporters. Despite this reputation as a tool for arranging virtual activities, only 46 percent of participants agree that Facebook virtual activities attract attention of rulers.

An index of perceptions about Facebook's political power is calculated by a factor analysis. It produced one dimension explaining 80 percent of total variation and reliability of this index is 0.90, calculated by Cronbach Alpha. 


\section{Determinants of Facebook Political Participation: Independent Variables:}

\section{Political Values}

In addition to basic demographic variables, a number of political and behavioral factors are included to the analysis. First set of independent variables target to measure political values of respondents. These variables are the self-positioning of the respondent on nationalism, leftright spectrum and conservatism scales. In this stage of analysis, a specific index to measure anomie is calculated.

“Anomie", a concept developed by Durkheim (1897), which means lack of social norms "normlessness". It describes a situation when social bonds between an individual and their community ties are broken and social identity of individuals is fragmented. This concept has been operationalized and measured by Sroles (1957) and heavily used in explaining sociopolitical developments in rapidly changing environments. Çarkoğlu and Kalaycığlu translated and adopted this scale to measure level of anomie in Turkish society as a determinant of conservatism. Several works targeting young people used this scale to present level of high anomie in Turkish society. (Çarkoğlu \& Kalaycığlu, 2009; Erdoğan, 2012).

The scale is a simple summation of answers given to these 10 questions. Cronbach's Alpha coefficient measuring internal validity of this scale is 0.68 , a relatively high score. Below figure presents a comparison of findings of different surveys. A survey conducted by Çarkoğlu and Kalaycığlu (2009) shows that 19 percent of Turkish population has a high anomie score -higher than 80 points-. Another survey conducted by the ARI Movement (2008) found that percentage of people having high anomie score is 37.7 among young people (15-27 ages) living in the urban areas of Turkey. Among participants of our survey, more than one third of them have a high anomie score. We believe that feeling of anomie plays an important role pushing people being politically active in the real life and in Facebook.

In addition to questions about some basic values and perceptions; political preferences of participants are also asked during interviews. In order to measure party identification of participants, major political parties represented in the parliament are listed in a randomized order and participant is asked to position herself on a 7 point scale. By using these scales, a factor analysis is conducted to derive common dimensions. This factor analysis provided us 
two dimensions; the first one explains 34 percent of total variation and positively loaded with pro-opposition and anti-AKP attitudes, labeled as CHP vs. AKP dimension. Second factor is positively correlated with pro-MHP attitudes and negatively correlated with BDP attitudes. This dimension is called as "MHP vs. BDP" dimension and has an explanatory power of 29 percent.

\section{Political Behaviors}

Major information sources of participants about politics are stated as websites. More than 80 percent of participations said that they are regularly getting information about politics through websites. Second group of popular information sources are newspapers (68 percent), Facebook (64 percent) and TV (63 percent). Twitter is not equally popular, only 43 percent of participants said that they are getting political information from Twitter. Blogs are not popular compared to other unconventional media sources such as websites or Facebook. Journals and radio are not preferred by participants. This figure shows that all kinds of unconventional or "new" media are not equally popular for young people. Websites and Facebook are preferred to Twitter and blogs. These figures showsthat all conventional media is not dead to same degree. Newspapers and TV are still popular as political information sources, while radio or journals are not preferred.

In order to facilitate data analysis, number of variables is reduced by using factor analysis. Factor analysis is generally used to reduce number of variables by using communalities between variables. Our analysis of political information sources produced two dimensions.

\section{Table 3. Dimensions of Political Information Sources-Factor Analysis Results (Factor}

\section{Loadings)}

\begin{tabular}{|lll|}
\hline & Factor 1 & Factor 2 \\
\hline TV & -0.03 & 0.72 \\
\hline Radio & 0.10 & 0.65 \\
\hline Newspapers & 0.30 & 0.68 \\
\hline Journals & 0.45 & 0.49 \\
\hline Websites & 0.58 & 0.33 \\
\hline Blogs & 0.80 & 0.10
\end{tabular}




\begin{tabular}{|lll|}
\hline Twitter & 0.73 & 0.02 \\
\hline Facebook & 0.69 & 0.13 \\
\hline $\begin{array}{l}\text { Explained } \\
\text { Variance }\end{array}$ & 28.20 & 22.90 \\
\hline Name & $\begin{array}{l}\text { Unconventional } \\
\text { Media }\end{array}$ & $\begin{array}{l}\text { Conventional } \\
\end{array}$ \\
\hline
\end{tabular}

Results of factor analysis are presented above with factor loadings. Factor loadings are coefficients varying between -1 and 1 , when absolute value of coefficient approaches to 1 , it indicated a stronger relationship, if it approaches to 0 , and it indicates a weak or non-existent relationship. Factors are labeled according to factor loadings of variables. First factor, explaining 28 percent of total variance is highly correlated with Blogs, Twitter, Facebook and Websites. Consequently we're labeling it as "unconventional media". Second dimension, explained 23 percent of variance is labeled as "conventional media" and it's strongly correlated with TV, newspapers, radio and journals. This analysis shows that information sources per se segregated empirically. We will use these dimensions as explanatory variables in following sections.

Table 4. Political Activities of Participants and Turkish Youth (Percentage of "I did" Answers")

\begin{tabular}{|c|c|c|c|}
\hline & Survey & $\begin{array}{l}\text { Turkish } \\
\text { Youth }\end{array}$ & $\begin{array}{l}\text { Subset } \\
\text { Turkish } \\
\text { Youth }\end{array}$ \\
\hline Voting & 89.0 & 48.0 & 58.1 \\
\hline $\begin{array}{l}\text { Being a member to the youth branch of a political } \\
\text { party }\end{array}$ & 13.3 & 9.0 & 12.9 \\
\hline $\begin{array}{l}\text { Being a member to of a political party except the youth } \\
\text { branch }\end{array}$ & 9.5 & 4.1 & 8.6 \\
\hline Canvassing in a political campaign & 6.6 & 5.0 & 11.8 \\
\hline Distributing brochures in a political campaign & 10.8 & 5.3 & 14.1 \\
\hline Petitioning about a local problem & 35.7 & 8.0 & 18.3 \\
\hline Petitioning about a personal problem & 44.1 & 7.3 & 14.1 \\
\hline
\end{tabular}




\begin{tabular}{|lccc|}
\hline Participating in a political demonstration & 47.9 & 11.3 & 22.6 \\
\hline Participating in a boycott & 31.5 & 6.8 & 15.1 \\
\hline $\begin{array}{l}\text { Participating in a protest activity conducted } \\
\text { internet }\end{array}$ & 48.7 & 7.2 & \\
\hline Being a member of a civil society organization & 20.5 & 4.4 & 18.3 \\
\hline
\end{tabular}

Political participation patterns of participants are presented above. Findings of above cited survey on political activities of Turkish youth is also included. In order to make a relatively meaningful comparison, we also included scores of a subset of the Turkish youth survey by filtering with employment status and $a^{2} e^{2}$ Voting is the most popular political activity of survey participants. Almost all of them voted with a majority of 90 percent. This activity also was the most frequent political activity according to the 2008 Survey; however proportion of those voted was less than half of respondents.Membership in a political party -in youth branches or not- is not popular among participants. Less than 10 percent of Turkish youth is a member of a political party, and this ratio is 13 percent of our participants and equivalent subset. Active participation to a campaign is also not among popular activities, and our sample seems less active, compared to the equivalent sample.

On the other hand, above table shows that unconventional political participation is very high among respondents of our survey. Although only 8 percent of Turkish youth signed a petition about local problems, this score is 5 times higher in our sample. This statistics is 2 times higher than the subset's average of 18 percent. The picture is same for the case of signing petition about a personal problem. Other dimensions of unconventional participation also expose such a difference. Percentage of those participated in a boycott is 32 percent (7 percent among Turkish youth), in a political demonstration is 48 percent (11 percent among Turkish youth).

According to these statistics, half of respondents participated in a protest activity conducted over the Internet; it was only 7 percent for Turkish youth and 18 percent of the equivalent sample. This difference may be attributed to increased penetration of the Internet. In 2008, Internet penetration was lower than 50 percent among the equivalent subset, and only one

\footnotetext{
${ }^{2}$ Number of participants of 2008 Survey is 804 , while the subset is composed of 93 people
} 
third of Turkish youth had regular access to Internet; last figures show that Internet penetration is about 60 percent in Turkish households. Consequently, increased Internet penetration may lead to increased protest activity over the Internet. Below sections of the paper will provide further data to discuss this relationship.

Table 5. Dimensions of Political Activities (Factor Loadings)

\begin{tabular}{|c|c|c|c|}
\hline & Factor 1 & Factor 2 & Factor 3 \\
\hline Voting & -0.03 & 0.43 & 0.01 \\
\hline $\begin{array}{l}\text { Being a member of the youth branch } \\
\text { of a political party }\end{array}$ & 0.64 & 0.04 & 0.04 \\
\hline $\begin{array}{l}\text { Being a member of a political party } \\
\text { except the youth branch }\end{array}$ & 0.69 & 0.12 & 0.00 \\
\hline Canvassing in a political campaign & 0.76 & 0.00 & 0.13 \\
\hline $\begin{array}{l}\text { Distributing brochures in a political } \\
\text { campaign }\end{array}$ & 0.82 & 0.08 & 0.03 \\
\hline Petitioning about a local problem & 0.07 & 0.10 & 0.89 \\
\hline Petitioning about a personal problem & 0.06 & 0.11 & 0.89 \\
\hline $\begin{array}{l}\text { Participating in a political } \\
\text { demonstration }\end{array}$ & 0.17 & 0.82 & 0.12 \\
\hline Participating in a boycott & 0.11 & 0.81 & 0.12 \\
\hline Explained Variance & 24.38 & 17.45 & 18.05 \\
\hline Name & $\begin{array}{l}\text { Conventional } \\
\text { Political } \\
\text { Participation }\end{array}$ & $\begin{array}{l}\text { Unconventional } \\
\text { Political } \\
\text { Participation }\end{array}$ & Petitioning \\
\hline
\end{tabular}

Factor analysis of political participation of respondents produced three different factors, parallel to previous studies (Erdoğan, 2001, Çarkoğlu, 2001 and Erdoğan, 2003). First factor 
explaining 25 percent of total variance is correlated with being a member of a political party (youth or not), canvassing and distributing brochures in a political campaign which are classified as "conventional methods of political participation". Consequently, we labeled this dimension as "conventional political participation".Second dimension is dominated by unconventional methods of political participation, such as participating in a political demonstration or a boycott. Participating in a protest activity over the Internet has also a higher factor loading with this dimension. This dimension is labeled as "unconventional political participation".

Final dimension explaining 18 percent of total variance is correlated with petitioning, about local or personal problems. This dimension is called as "petitioning".

The last general elections held on June 2011 give us an important opportunity to test political activities of participants. According to our statistics, 30 percent of participants tried to convince people for a candidate or a party. Same percent of them participated in a meeting of a candidate or a party. Another way of passive political activity, participating to a house meeting of a candidate or party is not popular: only 14 percent of participants had such an experience. It is clear that participants don't prefer active involvement in political campaigns: only 8 percent of participants distributed brochures and only 5 percent participated in doorto-door canvassing activities.

By using answers given to this question, an additive index of political activity in 2011 general elections is calculated. If a respondent participated in all activities, her score of political activity is 5. If she didn't participate in any of them, her score would be calculated as 0 . Reliability of this scale is measured as 0.71 with Cronbach Alpha coefficient. Average political activity score is 0.79 with a standard deviation of 1.2 .

\section{Facebook Usage and Attitudes}

We believe that political activities in Facebook are related with usage patterns of participants and frequency is one of the important indicator of Facebook usage and attitudes. Our survey shows that one third of participants spend less than 3 hours per week. 40 percent of participants spend between 3 and 10 hours per week, while 22 percent of participants are intense users with an average spending of 10 hours per week. Same table shows that one third 
of participants are always "online" on the Facebook. 20 percent of them visit their Facebook account 4-5 times per day, while one quarter of participants visit 2-3 time per day. A simple summation shows that more than 75 percent of participants visit their Facebook account once a day at minimum. Less frequent users only form 10 percent of participants.

Another indicator of Facebook usage behavior is number of friends of participants. According to our calculations, average number of friends of participants is about 340 with a standard deviation of 283, showing a high level of variation.By using time spent in Facebook and frequency of visiting Facebook pages, a simple index of Facebook usage intensity has been calculated with factor analysis technique. A single dimension explaining 70 percent of total variation has been produced and labeled as the Facebook Intensity index.Facebook provides different ways for communicating with friends and other people. People may prefer different tool for communicating with their friends and their usage patterns may be different. In order to discover alternative usage patterns and their effect on their political activities on the Facebook, we developed a set of questions to measure their usage preferences of different tools.

Table 6. Facebook Usage Patterns of Participants (Percent and Average)

\begin{tabular}{|lll|}
\hline & $\begin{array}{l}\text { Percentage of "I do" } \\
\text { Answers }\end{array}$ & Average \\
\hline Sending messages to my friend & 67.5 & 2.88 \\
\hline $\begin{array}{l}\text { Being informed about social } \\
\text { activities }\end{array}$ & 62.2 & 2.78 \\
\hline Reading my Wall & 56.4 & 2.76 \\
\hline Sending personal messages & 55.6 & 2.67 \\
\hline Writing on my Wall & 42.3 & 2.44 \\
\hline Participating to social activities & 40.0 & 2.38 \\
\hline Updating my profile and photos & 37.3 & 2.43 \\
\hline Participating to social groups & 36.2 & 2.22 \\
\hline Reading my friends' Walls & 31.8 & 2.25 \\
\hline Writing on my friends' Walls & 21.9 & 2.13 \\
\hline Inviting my friends to social & 18.2 & 1.80 \\
\hline
\end{tabular}




\begin{tabular}{|lll|}
\hline groups & & \\
\hline Forming a social group & 15.1 & 1.67 \\
\hline Arranging social activities & 15.0 & 1.68 \\
\hline
\end{tabular}

Our findings show that participants prefer using Facebook as an information and communication tool. Most popular activities are sending messages to their friends (67.5 percent) and being informed about social activities (62.2 percent). More than half of respondents regularly read their walls and 40 percent of them write on their walls. Participating to social activities is relatively less popular, similar to updating profiles and photos and participating to social groups. One third of participants read their friends' walls but only 22 percent write on these walls. Forming social groups and inviting their friends and arranging social activities are least popular activities.

Table 7. Dimensions of Facebook Usage Patterns (Factor Loadings)

\begin{tabular}{|lllll|}
\hline & $\mathbf{1}$ & $\mathbf{2}$ & $\mathbf{3}$ \\
\hline Reading my Wall & 0.10 & $\mathbf{0 . 7 4}$ & 0.05 \\
\hline Writing on my friends' Walls & 0.18 & $\mathbf{0 . 7 4}$ & 0.18 \\
\hline Reading my friends' Walls & 0.13 & $\mathbf{0 . 7 4}$ & 0.06 \\
\hline Writing on my Wall & 0.21 & $\mathbf{0 . 6 8}$ & 0.24 \\
\hline Updating my profile and photos & 0.16 & $\mathbf{0 . 6 1}$ & 0.37 \\
\hline Sending personal messages & 0.17 & 0.27 & $\mathbf{0 . 8 2}$ \\
\hline Sending messages to my friend & 0.20 & 0.19 & $\mathbf{0 . 8 5}$ \\
\hline Participating in social activities & $\mathbf{0 . 6 6}$ & 0.17 & 0.41 \\
\hline Forming a social group & $\mathbf{0 . 8 6}$ & 0.12 & 0.04 \\
\hline Inviting my friends to social groups & $\mathbf{0 . 8 6}$ & 0.15 & 0.12 \\
\hline Arranging social activities & $\mathbf{0 . 8 6}$ & 0.18 & -0.01 \\
\hline Participating in social groups & $\mathbf{0 . 7 3}$ & 0.18 & 0.28 \\
\hline Being informed about social activities & $\mathbf{0 . 5 8}$ & 0.18 & 0.33 \\
\hline Explained Variance & $\mathbf{2 8 . 3}$ & $\mathbf{2 1 . 1}$ & $\mathbf{1 5 . 4}$ \\
\hline & Arranging & Updating & Communicating \\
\hline
\end{tabular}


In order to discover common dimensions of Facebook usage patterns, a factor analysis has been conducted and three factors explaining 65 percent of total variation are derived. First factor has higher factor loadings from more active patterns such as forming a social group and inviting friends, arranging and participating in social activities. This dimension of Facebook usage explains 28 percent of variation, is labeled as "arranging" to refer its initiative taking nature.Second dimension is characterized with higher loadings from reading and writing her and her friends wall. It explains 21 percent of total variation and it's labeled as "updating".Final dimension is related with sending messages, that's why it's labeled as "communicating".

\section{Descriptive Statistics of Independent Variables}

Below table presents basic descriptive statistics of independent variables to be employed in our models.

Table 8. Descriptive Statistics of Independent Variables

\begin{tabular}{|c|c|c|c|}
\hline Category of Variables & & Mean & Std.Dev \\
\hline \multirow[t]{3}{*}{ Demographic Variables } & Gender $(1=$ male, $0=$ female $)$ & 0.55 & 0.49 \\
\hline & Ownership (0 to 6$)$ & 3.81 & 2.15 \\
\hline & Parental Education (1 to 4) & 1.80 & 0.78 \\
\hline \multirow[t]{4}{*}{ Political Values } & Party Distances & 0 & 1 \\
\hline & (CHP vs. AKP) & & \\
\hline & (MHP vs. BDP) & & \\
\hline & Anomie (0 to 100$)$ & 61.40 & 18.86 \\
\hline \multirow[t]{8}{*}{ Political Behaviors } & Media Usage & 0 & 1 \\
\hline & - Conventional & & \\
\hline & - Unconventional & & \\
\hline & Dimensions of Political & 0 & 1 \\
\hline & Participation & & \\
\hline & - Conventional & & \\
\hline & - Unconventional & & \\
\hline & - Petitioning & & \\
\hline
\end{tabular}




\begin{tabular}{|llll|}
\hline & Political Activity 2011 & 0.79 & 1.21 \\
\hline Facebook Usage & Usage Intensity & 0 & 1 \\
& & \\
\cline { 2 - 4 } & Facebook Usage Patterns & 0 & 1 \\
& -Arranging, & \\
& - Updating & & \\
& - Communicating & & \\
\hline
\end{tabular}

\section{Determinants of Political Participation in Facebook: Multivariate Analyses}

In order to discover determinants of political participation in Facebook, a series of multiple regression analyses are conducted. Multiple regression analysis is a tool allowing us to see direct effects of each independent on dependent variable, by controlling effects of other independent variables. We preferred to use Ordinary Least Squares regression method, assuming that correlations between independent variables are not too strong to violate basic assumptions of this method. Our analysis showed that correlation coefficients between independent variables are not greater than 0.2 with two exceptions: anomie's correlation between political positioning on "Other vs. AKP" is 0.39 and correlation between Facebook usage intensity and Facebook usage pattern of updating is 0.35 . Since these correlations don't directly affect overall structure of equations, we didn't exclude them from equations.

In our analysis, we had four different equations. First one is about determinants of political activity in Facebook during June 2011 general elections. We hypothesized that political activity in Facebook is a function of one's general political activities in Facebook, her perception about political power of Facebook and her real life political activities during these general elections.

Table 9. Determinants of Political Activity in June 2011 Elections (OLS Results)

\begin{tabular}{|llll|}
\hline & B & Beta & Sig. \\
\hline Constant & 0.73 & & 0.00 \\
\hline Indirect Expression & 0.24 & 0.16 & 0.00 \\
\hline Direct Expression & 0.80 & 0.56 & 0.00 \\
\hline Participation & 0.22 & 0.15 & 0.00 \\
\hline
\end{tabular}




\begin{tabular}{|llll|}
\hline $\begin{array}{l}\text { Political Activity } \\
2011\end{array}$ & 0.28 & 0.24 & 0.00 \\
\hline & & & \\
\hline Adj. R-Square & 0.51 & & \\
\hline F & 124.90 & Sig. F: & 0.00 \\
\hline
\end{tabular}

Above table presents findings of first regression analysis. B coefficients show magnitude and direction of change in dependent variable (political activities on Facebook) as independent variables increase by 1 point. For example, as one's position in Indirect Political Expression dimension increases by 1 point, her political activities on Facebook increases by 0.24 points; other factors remaining constant. Beta coefficients are standardized coefficients allowing us to compare explanatory variables. According to our table, most important determinant of political activities on Facebook is one's position in Direct Expression dimension. Finally, third column shows statistical significance of variables, if this score is greater than 0.10 , it is statistically not different than 0 , hence statistically insignificant.

According to our findings, as one's political participation in all dimensions increases, her tendency to make political activities in the last general elections increases. Among all these dimensions, Direct Expression has the biggest explanatory power vis-à-vis other variables, indicating that those tend to open their political preferences directly; they are more tended to make political activities. Similarly, political activities in real life arealso positive factors contributing to political activities in Facebook. As political activities are determined by political participation patterns, we want to discuss which factors determine each of these political participation patterns.

Table 10. Determinants of Facebook Political Participation: (OLS Results, Indirect Expression Dependent)

\begin{tabular}{|llll|} 
& B & Beta & Sig. \\
\hline (Constant) & -0.16 & & 0.53 \\
Gender Recoded & 0.02 & 0.01 & 0.85 \\
Ownership & 0.03 & 0.05 & 0.29 \\
Parental Education & 0.00 & 0.00 & 0.99 \\
\hline
\end{tabular}




\begin{tabular}{|c|c|c|c|}
\hline Anomie & 0.00 & 0.02 & 0.73 \\
\hline CHP vs. AKP & 0.21 & 0.22 & $\mathbf{0 . 0 0}$ \\
\hline MHP vs. BDP & -0.08 & -0.08 & 0.09 \\
\hline Unconventional Media & 0.21 & 0.21 & $\mathbf{0 . 0 0}$ \\
\hline Conventional Media & 0.12 & 0.12 & 0.01 \\
\hline Conventional & 0.09 & 0.09 & 0.05 \\
\hline \multicolumn{4}{|l|}{ Participation } \\
\hline Petitioning & 0.13 & 0.13 & 0.01 \\
\hline Unconventional & 0.22 & 0.22 & $\mathbf{0 . 0 0}$ \\
\hline \multicolumn{4}{|l|}{ Participation } \\
\hline Facebook Intensity & 0.05 & 0.05 & 0.35 \\
\hline Facebook Usage-Arranging & 0.02 & 0.02 & 0.70 \\
\hline Facebook Usage-Updating & 0.15 & 0.14 & 0.01 \\
\hline Facebook Usage-Communicating & 0.13 & 0.13 & 0.01 \\
\hline Adj. R-Square & 0.28 & & \\
\hline $\mathrm{F}$ & 10.10 & Sig. F: & 0.00 \\
\hline
\end{tabular}

Above table presents findings of multivariate regression analyses where Indirect Expression style ofpolitical participation in Facebook is dependent. Independent variables are demographic and socioeconomic status variables, political preferences, media usage for getting political information, different dimensions of political participation, Facebook usage intensity and Facebook usage patterns.

According to this table, demographic variables have no effect on Indirect Expression of political ideas in Facebook, their coefficients are statistically insignificant. Anomie is another independent variable with a insignificant coefficient. Meanwhile, political preferences matter. Those preferring CHP to AKP tend to have more Indirect Expression of political ideas. 1 point of increase in this dimension leads to 0.21 increase in our dependent variable. Similarly, those are located towards BDP than MHP, have higher scores on Indirect Expression scale.

Usage of media for getting political information is also affective in Indirect Expression way of political participation. First of all, more media usage means more Indirect Expression, 
since both dimensions have statistically significant effects. However, explanatory power of unconventional media usage is bigger than conventional media usage's effect: 0.21 vs. 0.12 .

Similarly all kind of political participation increases level of Indirect Expression of political ideas in Facebook, because all coefficients are statistically significant. But, unconventional political participation's effect doubles effects of other two dimensions of political participation. It seems that indirect political participation is strongly linked with Indirect Expression.

If we focus on Facebook usage attitudes, we observe that there is no relation between Facebook usage intensity of this dimension of Facebook political participation. On the other hand, analysis shows that there are significant differences between different dimensions of Facebook usage. While people preferring using Facebook as a more interactive tool to arrange and organize people, are not more tended to express indirectly their political ideas; two other dimensions have positive effects. Updating and Communicating dimensions of Facebook usage have positive impact on this style of Facebook politics.

Table 11. Determinants of Facebook Political Participation: (OLS Results, Direct Expression Dependent)

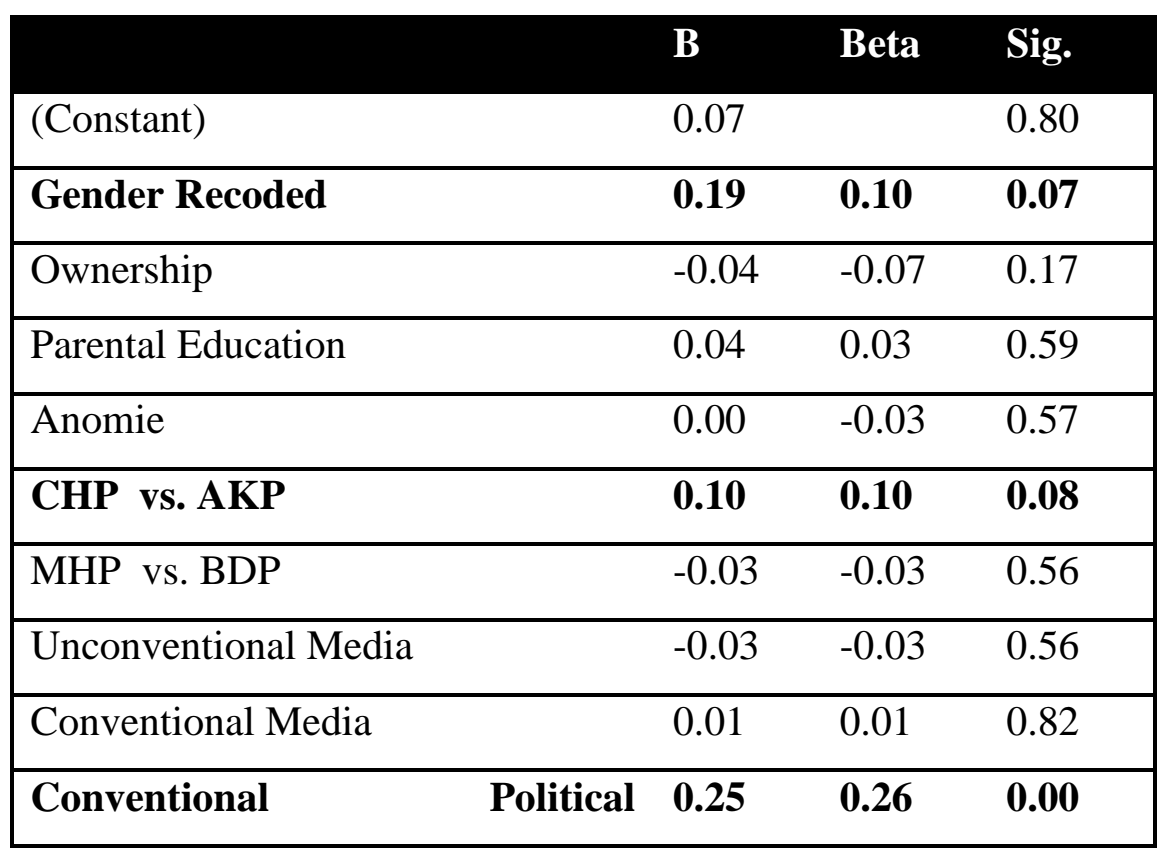




\begin{tabular}{|c|c|c|c|}
\hline Participation & & & \\
\hline Petitioning & -0.07 & -0.07 & 0.16 \\
\hline $\begin{array}{ll}\text { Unconventional } & \text { Political } \\
\text { Participation } & \end{array}$ & -0.01 & -0.01 & 0.84 \\
\hline Facebook Intensity & $\mathbf{0 . 1 0}$ & 0.10 & 0.10 \\
\hline Facebook Usage-Arranging & 0.07 & 0.07 & 0.21 \\
\hline Facebook Usage-Updating & 0.10 & 0.10 & 0.07 \\
\hline Facebook Usage-Communicating & 0.01 & 0.01 & 0.82 \\
\hline Adj. R-Square & 0.10 & & \\
\hline $\bar{F}$ & 3.66 & Sig. F: & 0.00 \\
\hline
\end{tabular}

Different than Indirect Expression dimension, there is a difference between male and female participants in terms of Direct Expression. Male participants tend more to use Direct Expression dimension compared to females ones. Among political variables, positioning on CHP vs. AKP dimension matters. As one's score shifts towards CHP by 1 point, her score in Direct Expression dimension scale increases by 0.1 points. Another factor positively affecting this behavior is conventional political participation and according to Beta coefficients it is the strongest explanatory variable. Media usage or other dimensions of political participation don't affect this dependent variable.

When Facebook usage and attitudes are taken into account, we observe that as one's Facebook usage intensity increases, her tendency to directly express her political views also increases. Finally, among Facebook usage patterns, only significant coefficient belongs to Updating dimension. People using Facebook to update themselves and their friends have more tendencies to directly express their political views. It is not surprising that political expression is considered as a part of updating function of Facebook.

Table 12. Determinants of Facebook Political Participation: (OLS Results, Participation Dependent)

\begin{tabular}{llll|} 
& B & Beta & Sig. \\
\hline (Constant) & -0.24 & & 0.35 \\
\hline
\end{tabular}




\begin{tabular}{|c|c|c|c|}
\hline Gender Recoded & 0.20 & 0.11 & 0.03 \\
\hline Ownership & 0.01 & 0.01 & 0.81 \\
\hline Parental Education & 0.12 & 0.10 & 0.05 \\
\hline Anomie & 0.00 & -0.04 & 0.46 \\
\hline Others vs. AKP & -0.06 & -0.06 & 0.25 \\
\hline Others vs. BDP & -0.02 & -0.02 & 0.73 \\
\hline Unconventional Media & 0.08 & 0.09 & 0.09 \\
\hline Conventional Media & -0.07 & -0.07 & 0.15 \\
\hline $\begin{array}{ll}\text { Conventional } & \text { Political } \\
\text { Participation } & \end{array}$ & 0.27 & 0.28 & 0.00 \\
\hline Petitioning & 0.06 & 0.06 & 0.22 \\
\hline $\begin{array}{ll}\text { Unconventional } & \text { Political } \\
\text { Participation } & \end{array}$ & -0.01 & -0.02 & 0.75 \\
\hline Facebook Intensity & 0.10 & 0.11 & 0.06 \\
\hline Facebook Usage-Arranging & 0.20 & 0.20 & 0.00 \\
\hline Facebook Usage-Updating & 0.08 & 0.08 & 0.12 \\
\hline Facebook Usage-Communicating & 0.00 & 0.00 & 0.94 \\
\hline Adj. R-Square & 0.23 & & \\
\hline $\mathrm{F}$ & 8.12 & Sig. F: & 0.00 \\
\hline
\end{tabular}

When Participation dimension is taken as the dependent variable, it's observed that demographic and socioeconomic factors continue to be statistically significant. Male users tend to participate more than female ones. As education of parents of participants increases, their scores in this dimension of political participation also increases. These differences may be understood as evidence for validity of resources hypothesis.

Political preferences and values are not effective factors, meaning that level of anomie or positioning in political spectra are not statistically significant. On the other hand, users of unconventional media have higher scores than other users. As new media becomes the major source for information; they tend to participate more.Among different dimensions of political participation; conventional political participation showing participants' current political 
activities is statistically significant, leading us to conclude that this kind of political participation in Facebook is a continuum of political activities in the real life.

As Facebook usage intensity increases, people's tendency to participate in these terms increases. Our major finding from this equation is that different styles of Facebook usage have different effects on political participation. Users having higher scores in Arranging dimension have a higher tendency to participate. And, users spending more time on updating also have higher participation scores.

\section{Discussion}

Our paper targets to discover dimensions of political participation in Facebook and their determinants. Data collected from university students using Facebook showed that political participation in Facebook is multidimensional and each dimensions are affected by different factors.

Our analysis showed that it is possible to define three different dimensions of political participation in Facebook (H4). A Facebook user may prefer to indirectly express her political opinions by posting, sharing and following; without declaring her political preferences. Or, she may prefer to openly state her political position by becoming a fan of a political candidate or liking him. Third option is more active compared to previous ones. She can discuss politics with her friend through messaging or chatting. Forming a political group or joining to a political group are grouped under this dimension.

Determinants of different dimensions of political participation in Facebook are also different. Our multivariate analyses showed thatIndirect Expression is affected by political preferences, media usage, and political participation in real life (H2). Different styles of Facebook usage have different effects. As respondents tend to use Facebook for updating and communicating, they tend to prefer this kind of political participation (H3). There is a significant difference between male and female respondents in regards to their Direct Expression of their political identities (H1). Political preferences also affect this dimension. However, conventional political participation is the biggest factor, showing that this kind of political activity is the continuum of real life political activities of the respondent. Those tend to be more active in 
conventional politics tend more to use these activities (H2). Facebook usage intensity and style are also affecting factors.

Demographic and socioeconomic variables significantly affect active participation dimension. Parental education showing a higher socioeconomic status is statistically significant (H1). Usage of unconventional media leads to more active involvement in politics, similar to conventional political participation (H2). As Facebook usage intensity increases, tendency to active participation also increases. Meanwhile, people that arrange activities in Facebook are more open to participate in this dimension, meaning that dimensions of political participation in Facebook matters (H3).

\section{References}

Arı Hareketi, (2008), TürkGençliğininSiyasalKatılımı., available at: http://www.ari.org.tr/index.php?option=com_content\&task=category\&sectionid=3\&i $\mathrm{d}=61 \&$ Itemid $=83$ 
Baumgartner, J., \& Morris, J. (2010).MyFace Tube politics: Social networking web sites and political engagement of young adults. Social Science Computer Review, 28(1), 24-44.

Bennett, W. L., \&Iyengar, S. (2008). A new era of minimal effects?The changing foundations of political communication.Journal of Communication, 58, 707-731.

Bryman, A. (2008). Social Research Methods (3rd ed.). Oxford, Oxford University Press.

Çarkoğlu, A. \&Kalaycıŏlu, E. (2009).The Rising Tide of Conservatism in Turkey.New York, Palgrave-Macmillan.

Çarkoğlu, A. (2001). Türkgençliğivesiyasalkatılım.In KatılveGeleceğiniYarat.İstanbul, ARI DüşünceveToplumsalGelişimDerneğiYayınları.

Dhavan, V. S., Cho, J., Eveland, W.P., \&Kwak, N. (2005). Information and expression in a digital age: Modeling internet effects on civic participation. Communication Research October, 32, 531-565.

Erdoğan, E. (2001). Türkgençliğivesiyasalkatılımboyutları: Birkatılımendeksidenemesi. In KatılveGeleceğiniYarat .İstanbul, ARI

DüşünceveToplumsalGelişimDerneğiYayınları.

Erdoğan, E. (2003).Türkgençliğivesiyasalkatılım: 1999-2003. In KatılveGeleceğini Yarat II.İstanbul, ARI DüşünceveToplumsalGelişimDerneğiYayınları.

Erdoğan, E. (2009). Olasılıksızlığınkuramınıaramak: Türkgençliğivesiyasalpartilerekatılım. In Boyraz, C. (Ed.), Gençlertartışıyor: SiyaseteKatılım, SorunlarveÇözümÖnerileri. İstanbul, TÜSES Yayınları

Erdoğan, E. (2012). TEGV GönüllülükAraştırmaları.İstanbul, TEGV Yayınları.

Kalaycıoğlu, E. (2008). Türkiye'dedemokrasininpekişmesi: Birsiyasalkültürsorunu. In Yazıc1, S., Gözler, K. \&Keyman F. (Eds.), Essays in Honor of Ergun Özbudun, Ankara, AnkaraYetkinYayınları.

Kwak, N.,Williams, A.,Wang, X., \& Lee, H. (2005). Talking politics and engaging politics: An examination of the interactive relationships between structural features of political talk and discussion engagement. Communication Research, 32, 87-111.

Mutz, D. (2002). Cross-cutting social networks: Testing democratic theory in practice. American Political Science Review, 96(1), 111-126.

Polat, K. R. (2005). The internet and political participation: Exploring the explanatory links, European Journal of Communication, 20 (4), 435-459.

Quintelier, E. \&Vissers, S. (2008). The effect of internet use on political participation.Social Science Computer Review, (26:4), 411-427. 
Salganik, M. J. \&Heckathorn, D. D. (2004).Sampling and estimation in hidden populations using respondent - driven sampling.Sociological Methodology, 34, 193-239

Scheufele, D. A., \& Shah, D. V. (2000). Personality strength and social capital: The role of dispositional and informational variables in the production of civic participation. Communication Research, 27(2), 107-131.

Valenzuela, S., Park, N., \&Kee, K. F. (2008). Trust, participation and Facebook: The impact of social network sites on college students' social capital. International Symposium on Online Journalism held in Austin, 4-5 April 2008. University of Texas.

Vitak, J., Zube, P., Smock, A., Carr, T.C., Ellison, N., \& Lampe, C. (2011). It's Complicated: Facebook users' political participation in the 2008 election. Cyberpsychology, Behavior, and Social Networking, 14(3), 107-114. 